\title{
Effect of Inoculations of Trichoderma viride and Saccharomyces cerevisiae Mixed Culture on Chemical Composition, Fiber, Digestibility and Theobromine Cocoa Pod Fermentation
}

\author{
Muhammad Askari Zakariah \\ State Islamic College of Al Mawaddah Warrahmah \\ Jl. Pondok Pesantren No. 10 Kolaka, Sulawesi Tenggara, 93516, Indonesia. \\ Tel: +62-405-2323229 E-mail: m.askari.zakariah@mail.ugm.ac.id \\ (Received: Sept 3, 2015; Reviewed: Nov 11, 2015; Accepted: Nov 25, 2016)
}

\begin{abstract}
The objective of the study was to identify the effect of Trichoderma viride and Saccharomyces cerevisiae inoculant on chemical compositions, digestibility, and theobromine concentration of fermented cocoa pod. This experiment consisted of four treatments, namely cocoa pods without fermentation as control (R0); fermentation of cocoa pods with inoculant $T$. viride (R1); fermentation of cocoa pods with inoculant $S$. cerevisiae (R2); and fermentation of cocoa pods with inoculant $T$. viride and $S$. cerevisiae mixed culture (R3). Each treatment had 3 replicates, and then was fermented for 10 days. Variables observed were the chemical compositions i.e dry matter (DM), organic matter (OM), crude protein (CP), ether extract (EE), crude fiber (CF), nitrogen free extract (NFE), fiber fraction (Neutral detergent fiber and acid detergent fiber), in vitro digestibility, and theobromine concentration. Data were analysed by one-way analysis of variance and followed by Duncan's new multiple range test (DMRT), if there were any significant difference. Results showed the inoculum affected $(\mathrm{P}<0.05)$ the chemical composition, fiber fraction and in vitro digestibility. However, theobromine was not detected on cocoa pod without fermentation and fermentation. Compared to group R0, inoculation with $T$. viride and $S$. cerevisiae mixed culture $(\mathrm{P}<0.05)$ resulted in higher DM concentration $(92.78 \%$ vs $89.72 \%$ respectively), higher CP $(7.43 \%$ vs $5.63 \%$ respectively), higher NDF (79.41\% vs $61.18 \%$ respectively), higher ADF $(73.04 \%$ vs $47.94 \%$ respectively), but was not significantly different on DM and OM digestibility ( $21.22 \%$ vs $22.24 \%$, and $22.67 \%$ vs $24.31 \%$ respectively) than cocoa pod without fermentation. It is concluded that inoculant $T$. viride and $S$. cerevisiae mixed culture increased CP concentration, but had no effect on in vitro digestibility.
\end{abstract}

Keywords: Cocoa pod; fermentation, Trichoderma viride, Saccharomyces cerevisiae

\section{Introduction}

Limited availability of forage makes man look for other alternative feeds as partial or total replacement. Plantation wastes to be one option in dealing with the issue of the lack of forage availability in the dry season, but their waste products could also pollute the environment. According to Ditjen Perkebunan (2012), there were approximately $1,745,789$ ha of cocoa plantation in 2011 .
Cocoa pod contain various minerals. Toharmat et al. (2005), reported that feeding cocoa pod to Etawa as a fiber source also provide $\mathrm{Mg}$ and $\mathrm{Zn}$ in a higher concentration than those provided by grass, bark coffee, and rice straw. Wahyuni et al. (2008) reported that fermented cocoa pod could be used as animal feed in growing goats up to the level of $40 \%$. Puastuti et al. (2010) reported that a ration based on cocoa pod without ammonia- 
tion but with organic Zn supplementation resulted in weight gain equivalent to the daily ration of grass-based, supported by sufficient consumption rate and nutrient digestibility, $\mathrm{N}$ retention and good fermentation characteristics. Ginting (2004) reported that pod husks of more than $15 \%$ in the ration could reduce performances of goats.

Cocoa plantation wastes such as pod husks are commonly just piled and left to degrade in the field after being harvested. This practice could cause discomforting odor that cause disease to the cocoa plants. Pod husks contained anti nutritive substances such as theobromine that limits its level of inclusion in the diets. Efforts to improve the nutritive quality of the cocoa pod included, drying, addition of urea (ammoniation), and fermentation. The objective of this study was to investigate the effect of fermenting cocoa pod using different types of inoculant on the chemical composition, digestibility and thebromine concentration. The objective of the study was to identify the effect of Trichoderma viride and Saccharomyces cerevisiae inoculant on chemical compositions, digestibility, and theobromine concentration of fermented cocoa pod.

\section{Materials and Method}

The experiments were performed at the Laboratory Animal Food Technology, Laboratory of Biochemistry of Nutrition, Food Animal Nutrition Department, Faculty of Animal Science, Gadjah Mada University. Instrument is used included weights capacity $10 \mathrm{~kg}$ with sensitivity of $0.1 \mathrm{~kg}$, sealer and vaccum, grinder with sieve diameter's $1 \mathrm{~mm}$, analytic weights with sensitivity of $0.0001 \mathrm{~g}$,
$\mathrm{pH}$ meter, digital thermometer, oven, tube, high performance liquid chromatoghraphy Knauer tipe UV 6000 LP. Substance used included cocoa pod, inoculant of L. plantarum, Inoculant of $S$. cerevisiae, cassava meal, water, chemical for analysis proximate, chemical for parameter ruminal fermentation, chemical for theobromine analysis, and chemical for in vitro digestibility.

\subsection{Substrate Preparation, Fermentation and Treatments}

Fresh Cocoa pods were collected from a traditional farming Gunung Kidul Regency. Cocoa pods cut to size of 1 x $5 \mathrm{~cm}$ and sun-dried for 10 hours to decrease the water concentration. Two species of fungi were used as inoculants, namely Trichoderma viride and Saccharomycess cerevisiae.

Fermentation was conducted at laboratory scale in a room that was sterile. The room was watered with disinfectant, the tools were sterilised with alcohol $(90 \%)$. Cocoa pods were fermented in fermentor bag (as silo), and inoculation with $T$. viride and S.cerevisiae was performed at $1 \%$ dry matter, by mixing and spreading the inoculant evenly. Each silo was made to be aerobic by making a hole.The length of fermentation was set at 10 days at room temperature (Nelson and Suparjo, 2011; Ginting and Krisnan, 2006).

Three processing treatments and one control treatment were as follows:

- R0: Unfermented cocoa

- R1: Cocoa pod fermentation treatment using $T$. viride

- R2: Cocoa pod fermentation treatment using $S$. cerevisiae 
- R4 Cocoa pod fermentation using $T$. viride + S. cerevisiae

\subsection{Chemical Analysis}

Samples of dried silages were analyzed for their chemical compositions by proximate analyses (AOAC, 2005). Neutral Detergen Fiber (NDF) and Acid Detergen Fiber (ADF) analyses were performed according to the procedures of Van soest, (1987). In vitro digestibility study was performed according to the procedures of Tilley and Terry (1963) at Biochemical Nutrition Laboratory, of Animal Science Faculty, the Gadjah Mada University. Theobromine analysis to was conducted as recommended by European Food Safety Authority (2008) using HPLC (AOAC, 2005).

Data of chemical composition, fiber fraction, and in vitro digestibility were analyzed by analysis of variance (ANOVA) and followed by Duncan's new multiple range test (DMRT) if there were any significant differences (Steel et al., 1993). All statistical calculation were performed using software of Statistical Product and Service Solution version 16.0 (Soleh, 2005).

\section{Results and Discussion}

\subsection{Proximate and fiber fraction composi- tion of fermented cocoa pod}

The proximate compositions were shown in Table 1. The fermented cocoa pods had higher dry matter content than that of the unfermented cocoa pod. The Increased dry matter contents of the fermented cocoa pod might be caused by fungal growth in the cocoa pods. The growth of fungi was characteritically slower than that of bacte- rial Trichoderma viride secreted cellulose at day 8 , and influenced dry matter concentration. Suparjo et al. (2009) reported that fungi would utilized the organic matter from substrate and caused losses in dry matter. Mulato and Widyatomo (2003) showed that time of fermentation could affect the dry matter concentration of substrates.

Crude protein concentrations were significantly affected by the type of inoculants. Inoculation with $T$. viride have highest effect on crude protein level. Ginting and Krisnan (2006), showed that fermentation using Trichoderma sp as an inoculant increased the crude protein concentration of the substrates. In the current experiment the crude protein concentration was lower when treated with $T$. viride and $S$. cerevisiae mixed culture, which could be due to any negative interaction between both of inoculant.

Fungal inoculation significantly increased crude fiber contents of the fermented cocoa pods. This higher crude fiber concentration could be caused by increased composition of cell wall, of the hyfa fungal. Utomo (2001), reported that the crude fiber was organic matter which was divided to cellulose, hemicellulose, and lignin. All of these components were found in the fungal hyfa. Cocoa pods fermentation with $T$. viride and $S$. cerevisiae mixed culture showed higher free extract nitrogen concentrations. During the stationary phase, the $T$. viride used the substrate free extract nitrogen before degrading the cellulose. Kamaraet al. (2008) showed that glucose at early phase was used by $T$. viride for growing and then started to degrade the fiber fraction. The fiber fraction are presented in Table 2 . 
Tabel 1. Change chemical composition unfermented cocoa pod (R0), fermented cocoa pod were inoculated T. viride (R1), inoculated $S$. cerevisiae (R2), inoculated $T$. viride and $S$. cerevisiae mixed culture (R3).

\begin{tabular}{ccccccc}
\hline Variabel & DM & OM $^{\text {ns }}$ & CP & EE $^{\text {ns }}$ & CF & NFE \\
\hline R0 & $89,72^{\mathrm{a}}$ & 90,55 & $5,63^{\mathrm{a}}$ & 1,71 & $31,08^{\mathrm{a}}$ & $51,93^{\mathrm{d}}$ \\
R1 & $91,94^{\mathrm{b}}$ & 85,30 & $9,57^{\mathrm{d}}$ & 2,41 & $35,99^{\mathrm{c}}$ & $37,11^{\mathrm{b}}$ \\
R2 & $92,7^{\mathrm{b}}$ & 84,07 & $8,5^{\mathrm{c}}$ & 2,43 & $31,83^{\mathrm{b}}$ & $41,12^{\mathrm{c}}$ \\
R3 & $92,78^{\mathrm{b}}$ & 84.09 & $7,43^{\mathrm{b}}$ & 2,44 & $40,03^{\mathrm{d}}$ & $34^{\mathrm{a}}$ \\
\hline
\end{tabular}

a, b, and different supercripts at the same rows indicate significant difference $(P<0,05)$

${ }^{\mathrm{n}}$ non significant

Neutral detergent fiber and acid detergent fiber concentrations were significantly higher in the fermented cocoa pod compared to the unfermented ones. Fungi types affected the NDF and ADF concentration of fermented cocoa pod. Cell wall increased during the prolonged time of fermentation. This result differed to that reported by Alemawor et al. (2009), showing that cocoa pods fermented with Aspergillus niger have lower cell wall contents.

Table 2. Change fiber fraction concentration unfermented cocoa pod (R0), fermented cocoa pod were inoculated $T$. viride (R1), inoculated $S$. cerevisiae (R2), inoculated $T$. viride and $S$. cerevisiae mixed culture (R3).

\begin{tabular}{ccc}
\hline Variable & $\begin{array}{c}\text { Neutral Detergent } \\
\text { Fiber }\end{array}$ & $\begin{array}{c}\text { Acid Detergent } \\
\text { Fiber }\end{array}$ \\
\hline R0 & $61,18^{\mathrm{a}}$ & $47,94^{\mathrm{a}}$ \\
R1 & $74,66^{\mathrm{b}}$ & $67,32^{\mathrm{b}}$ \\
R2 & $79,36^{\mathrm{c}}$ & $73,93^{\mathrm{c}}$ \\
R3 & $79,41^{\mathrm{c}}$ & $73,04^{\mathrm{c}}$ \\
\hline
\end{tabular}

a, b, and different supercripts at the same rows indicate significant difference $(P<0,05)$

${ }^{\text {ns }}$ non significant

\subsection{In vitro digestibility of cocoa pod}

\section{fermentation}

The effects of fermentation and type of inoculants on the in vtiro digestibility are shown in Table 3. In vitro digestibility of substrate dry matter and organic matter were significantly affected by fermentation. Unfermented cocoa pod have higher DM and OM digestibility than those fermented with T. viride, but were not significantly different to than those fermented using inoculant of $T$. viride and $S$. cerevisiae as a mixed culture. Utomo (2001), reported that ADF was difficult to be degraded such that it could become an inhibitor in feed. Yunus (1997) reported that factors that affected in vitro digestibility were composition of feed, ruminal fluid temperature, time of incubation and analysis method.

Table 3. In vitro digestibility of unfermented cocoa pods (R0), fermented cocoa pods inoculated with $T$. viride (R1), S. cerevisiae (R2), T. viride and $S$. cerevisiae mixed culture (R3).

\begin{tabular}{ccc}
\hline Variabel & DM digestibility & OM digestibility \\
\hline R0 & $22,24^{\mathrm{b}}$ & $24,31^{\mathrm{b}}$ \\
R1 & $10,69^{\mathrm{a}}$ & $12,59^{\mathrm{a}}$ \\
R2 & $11,71^{\mathrm{a}}$ & $13,57^{\mathrm{a}}$ \\
R3 & $21,22^{\mathrm{ab}}$ & $22,67^{\mathrm{ab}}$ \\
\hline
\end{tabular}

a, band $\mathrm{c}$ different supercripts at the same rows indicate significant difference $(P<0,05)$

${ }^{\mathrm{n}}$ non significant

The theobromine concentration of fermented and unfermented cocoa pods are presented in Table 4. Theobromine concen- 
tration of unfermented and fermented cocoa pods were not detected by HPLC.This was possibly caused by the pre-preparation procedures including sun dried for 10 hours, this process might have reduced theobromine concentration. Sukha (2003), showed that dried and boiled could decrease theobromine concentration.

Table 4. Theobromine concentrations of unfermented cocoa pods (R0), fermented cocoa pod inoculated with $T$. viride (R1), S. cerevisiae (R2), T. viride and $S$. cerevisiae mixed culture (R3).

\begin{tabular}{cc}
\hline Variable & ${\text { Theobromine }(\mathrm{ppm})^{\mathrm{ns}}}^{\mathrm{R}}$ \\
$\mathrm{R} 0$ & $<0,03$ \\
$\mathrm{R} 1$ & $<0,03$ \\
$\mathrm{R} 2$ & $<0,03$ \\
$\mathrm{R} 3$ & $<0,03$ \\
\hline
\end{tabular}

\section{Conclusion}

Inoculation with $T$. viride and $S$. cerevisiae mixed cultures in fermenting cocoa pods affected the chemical composition and fiber fraction. However it does not affect the in vitro digestibility of DM and OM of cocoa pod. The theobromine concentration of the fermented and unfermented were not detected.

\section{References}

Alemawor, F., V. P. Dzogbefia, E. O. K. Oddoye, and J. H. Oldham. (2009). Enzyme cocktail for enhacing poultry utilisation of cocoa pod husk. Sci. Res. Essay. 4 (6): 555 - 559.

Association of Official Analytical Chemist. (2005). Official Methods of Analysis. $18^{\text {th }}$ Ed. The Association of Official Analytical Chemist. Washington, DC.
Astuti, M. (1980). Rancangan Percobaan. Fakultas Peternakan. Universitas Gadjah Mada. Yogyakarta.

Direktorat Jendral Perkebunan. (2011). Luas area dan produksi perkebunan seluruhIndonesia.http://ditjenbun.deptan. go.id/cigraph/index.php/viewstat/ komoditiutama/4-Kakao. Diakses pada 19/09/2012.

Ginting, S. P. (2004). Tantangan dan peluang pemanfaatan pakan lokal untuk pengembangan peternakan kambing di Indonesia. Proceeding Lokakarya Nasional Kambing Potong: 61 - 77.

Ginting, S. P. and R. Krisnan. (2006). Pengaruh fermentasi menggunakan beberapa strain trichoderma dan masa inkubasi berbeda terhadap komposisi kimiawi bungkil inti sawit. Proceeding Seminar Nasional Teknologi Peternakan dan Veteriner: 939 - 944.

Kamara, D. S., S. D. Rachman, andS. Gaffar. (2008). Enzymatic degradation of cellulose from banana stalks for glucose production using cellulolytic activity of Trichoderma viride. Proceeding of The International Seminar on Chemistry. 692-696.

Mulato, S. and S. Widyatomo. (2003). Teknik Budidaya dan Pengolahan Hasil Tanaman Kakao. Pusat Penelitian Kopi dan Kakao Indonesia. Jember.

Puastuti, W., D. Yulistiani, and Supriyati. (2008). Ransum berbasis kulit buah kakao diperkaya mineral: tinjauan pada kecernaan dan fermentasi rumen in vitro. Proceeding Seminar Nasional Teknologi Peternakan dan Veteriner 
$442-448$.

Sukha, A. D. (2003). The utilization of cocoa and cocoa by-product. Cocoa research unit. UWI.

Suparjo, K. G. Wiryawan, E. B. Laconi, and D. Mangunwidjaja. (2009). Perubahan komposisi kimia kulit buah kakao akibat penambahan mangan dan kalsium dalam biokonversi dengan kapang Phanerochaetachrysosporium. Media Peternakan 32 (3): $204-211$

Soleh, A. Z. (2005). Ilmu Statistika Pendekatan Teoritis dan Aplikatif disertai Contoh Penggunaan SPSS. Penerbit Rakayasa Sains.Bandung.

Steel, R.G.D and J.H. Torrie. (1993). Prinsip dan Prosedur Statistika. Bambang Sumantri. Gramedia. Jakarta

Tillman, A. D., H. Hartadi, and S. Reksohadiprojo. (1998). Ilmu Makanan Ternak Dasar. Gadjah Mada University Press. Yogyakarta.

Tilley, J.M.A. and R.A. Terry. (1963). A two stage technique for in the in vitro digestion of forage crops. J. Grassland Soc. $18: 104$.

Toharmat, T., E. Nursasih, R. Nazilah, N.
Hotimah, T. Q. Noerzihad, N. A. Sigit, and Y. Retnani. (2006). Sifat fisik pakan kaya serat dan pengaruhnya terhadap konsumsi dan kecernaan nutrien ransum kambing. Media Peternakan. 29 (3): 146 - 157.

Utomo, R. (2001). Penggunaan Jerami Padi Sebagai Pakan Basal: Suplementasi Sumber Energi dan Protein Terhadap Transit Partikel Pakan, Sintesis Protein Mikrobia, Kecernaan, dan Kinerja Sapi Potong. Disertasi. Fakultas Peternakan. Universitas Gadjah Mada. Yogyakarta.

Van Soest, P. J. (1994). Nutritional Ecology of The Ruminant. Cornell university Press. London.

Wahyuni, T. H., I. Sembiring, and W. J. Sihombing. (2008). Tape kulit buah kakao sebagai pakan kambing boerka. Jurnal Agribisnis Peternakan 4 (2): 65 68

Yunus, M. (1997). Pengaruh Umur Pemotongan Spesies Rumput terhadap Produksi Komposisi Kimia, Kecernaan In vitro dan In Sacco. Skripsi. Fakultas Pascasarjana Universitas Gadjah Mada, Yogyakarta. 